\title{
HUBUNGAN LAMA PEMBERIAN ASI DAN BERAT LAHIR DENGAN KEJADIAN STUNTING PADA BALITA DI WILAYAH KERJA PUSKESMAS SIULAK MUKAI KABUPATEN KERINCI TAHUN 2019
}

\author{
Selfi Angriani ${ }^{1)}$, Merita $^{2)}$, Aisah $^{3)}$ \\ ${ }^{1,2,3}$ Program Studi Ilmu Gizi STIKes Baiturrahim Jambi \\ Email: selfi.angriani97@gmail.com
}

\begin{abstract}
The incidence of stunting in infants is one of the global nutritional problems. The prevalence of stunting in Kerinci Regency on 2017 is 35.0\%. The purpose of this study was to determine the relationship between duration of breastfeeding and birth weight with the incidence of stunting in the work area of Community Health Centres of Siulak Mukai in 2019. This study used a cross sectional design that carried out in the work area of Community Health Centres of Siulak Mukai on May, 2019. The population in the study amounted to 311 toddlers. Samples in the study were 74 toddlers with proportional random sampling technique. Data collection was using questionnaire tools and measurement of nutritional status using microtoise. Data was analyzed univariate and bivariate (chi-square test). The results showed that the most had normal nutritional status (Height/Age) (63.5\%), duration of breastfeeding $\geq 2$ years $(67.6 \%)$, and birth weight $\geq 2500$ grams $(66.2 \%)$. The chi-square analysis showed a significant difference between the duration of breastfeeding and the incidence of stunting $(p=0,000)$, birth weight with the incidence of stunting $(p=0,000)$. Therefore, it is expected for mothers of children under five to implement exclusive breastfeeding and continue breastfeeding until the age of 2 years.

Keywords: Birth weight, Duration of breastfeeding, Kerinci, Stunting, Toddlers
\end{abstract}

\begin{abstract}
ABSTRAK
Kejadian stunting pada balita merupakan salah satu permasalahan gizi secara global. Prevalensi stunting di Kabupaten Kerinci tahun 2017 yaitu sebesar 35,0\%. Tujuan penelitian ini adalah untuk mengetahui hubungan lama pemberian ASI dan berat lahir dengan kejadian stunting di wilayah kerja Puskesmas Siulak Mukai tahun 2019. Penelitian ini menggunakan desain cross sectional yang dilaksanakan di Wilayah Kerja Puskesmas Siulak Mukai pada bulan Mei tahun 2019. Populasi pada penelitian berjumlah 311 balita. Sampel pada penelitian yaitu 74 balita dengan teknik proporsional random sampling. Pengumpulan data menggunakan alat bantu kuesioner dan pengukuran status gizi menggunakan microtoise. Analisa data dilakukan secara univariat dan bivariat (chisquare test). Hasil penelitian menunjukkan bahwa sebagian besar memiliki status gizi normal (TB/U) $(63,5 \%)$, lama pemberian $\mathrm{ASI} \geq 2$ tahun $(67,6 \%)$, dan berat lahir $\geq 2500$ gram $(66,2 \%)$. Hasil analisa chi-square menunjukkan ada signifikan antara lama pemberian ASI dengan kejadian stunting $(p=0,000)$, berat lahir dengan kejadian stunting $(p=0,000)$. Oleh sebab itu, diharapkan kepada ibu balita untuk menerapkan ASI Ekslusif dan melanjutkan pemberian ASI hingga usia balita 2 tahun.
\end{abstract}

Kata Kunci: balita, berat lahir, kerinci, pemberian asi, stunting 


\section{PENDAHULUAN}

Kejadian stunting pada balita merupakan salah satu permasalahan gizi secara global. Berdasarkan data UNICEF 2000-2007 menunjukkan prevalensi kejadian stunting di dunia mencapai $28 \%$. Kejadian stunting pada balita lebih banyak terjadi di negara berkembang. Hal ini dibuktikan dengan prevalensi kejadian stunting pada balita di negara berkembang sebesar 30\% (Unicef Report 2009). Indonesia adalah negara berkembang yang memiliki permasalahan yang kompleks terutama dalam masalah gizi. Gizi di Indonesia atau negara berkembang lain memiliki kasus gizi yang berbeda dengan negara maju, yaitu Indonesia memiliki kasus gizi ganda yang artinya status gizi yang menunjukkan keadaan disatu sisi daerah terdapat gizi kurang dan di sisi lain terdapat gizi lebih.

Stunting merupakan kondisi kronis buruknya pertumbuhan linear seorang anak yang merupakan akumulasi dampak berbagai faktor seperti buruknya gizi dan kesehatan sebelum dan setelah kelahiran anak tersebut (Fikawati dkk, 2017). Berdasarkan data dari Riset Kesehatan Dasar (Riskesdas) tahun 2018 jumlah status gizi sangat pendek dan pendek pada balita dari tahun ketahun mengalami peningkatan dimana pada tahun 2013 sebanyak $18 \%$ dan meningkat menjadi $18,8 \%$ pada tahun 2018 . Sementara itu, di Provinsi Jambi proporsi status gizi sangat pendek dan pendek menempati urutan ke 19 yaitu sebesar 29,5\% (Kemenkes RI, 2018). Hal ini menunjukan bahwa kejadian stunting di Provinsi Jambi menjadi masalah kesehatan

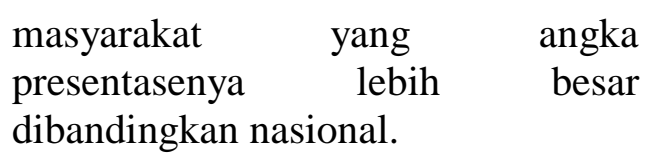
Menurut data Profil Kesehatan Provinsi Jambi (2017) terdapat enam Kabupaten yang memiliki prevalensi stunting di atas prevalensi Provinsi Jambi yaitu Kabupaten Sarolangun (37,3\%), Kerinci $(35,0 \%)$, Tanjung Jabung Barat (29,2\%), Batang Hari $(28,1 \%)$, Kota Sungai Penuh $(27,6 \%)$ dan Merangin (25,4\%). Berdasarkan data bahwa dari 5 puskesmas yang ada di Kabupaten Kerinci Puskesmas dengan angka kejadian stunting tertinggi ada pada Puskesmas Siulak Mukai yaitu berjumlah 29 angka kejadian. Jumlah balita usia 24-59 bulan yang ada di Wilayah Kerja Puskesmas Siulak Mukai berjumlah 311 anak. Dimana penelitian ini dilakukan pada ibu yang mempunyai anak usia balita yaitu berusia 24-59 bulan.

Stunting yang terjadi pada balita disebabkan juga oleh beberapa faktor, diantaranya akibat gangguan pertumbuhan dalam kandungan, kurang gizi mikro, asupan energi yang kurang, infeksi, pendapatan keluarga, umur pemberian ASI, faktor keturunan dan pengetahuan. Jika hal ini terjadi pada usia balita, maka menyebabkan gangguan pertumbuhan (Aruben, dkk, 2018). Faktor determinan terjadinya anak stunting diantaranya adalah asupan energi dan protein. Kecukupan energi pada anak dapat berasal dari ASI dan makanan pendamping. Selain faktor asupan, riwayat berat badan lahir rendah (BBLR) juga dapat menjadi faktor risiko. Kondisi BBLR merupakan indikator kesehatan masyarakat karena keterkaitannya dengan angka 
kematian dan kesakitan. Bayi dengan BBLR dapat mengalami hambatan pertumbuhan. Riwayat pemberian ASI eksklusif juga berpengaruh terhadap terjadinya anak stunting. Air Susu Ibu (ASI) merupakan makanan yang penting untuk anak. Anak usia 0-6 bulan memerlukan ASI eksklusif dikarenakan ASI merupakan makanan terbaik untuk anak. Selain dari faktor asupan, riwayat BBLR dan ASI eksklusif, faktor pendidikan ibu juga dapat menjadi faktor penyebab terjadinya kejadian stunting. Pendidikan juga dapat menjadi salah satu faktor risiko kejadian stunting (Nuryanto \& Vaozia, 2016).

Berdasarkan uraian di atas maka tujuan penelitian ini adalah untuk menganalisis hubungan lama pemberian ASI, penyakit infeksi dan faktor genetik dengan kejadian stunting di Wilayah Kerja Puskesmas Siulak Mukai Kabupaten Kerinci Tahun 2019. Berikut tabel jumlah kejadian stunting di kabupaten Kerinci tahun 2018.

Tabel 1. Jumlah Kejadian Stunting di Kabupaten Kerinci Tahun 2018

\begin{tabular}{clcc}
\hline No & Kecamatan & Puskesmas & Jumlah \\
\hline 1 & Danau Kerinci & Sanggaran Agung & 3 \\
2 & Sitinjau Laut & Hiang & 15 \\
3 & Keliling Danau & Jujun & 8 \\
4 & Siulak Mukai & Siulak Mukai & 29 \\
5 & Air Hangat & Semurup & 1 \\
\hline & Jumlah & & $\mathbf{5 6}$ \\
\hline
\end{tabular}

Sumber: Dinas Kesehatan Kabupaten Kerinci tahun 2018

\section{METODE PENELITIAN}

Penelitian ini menggunakan desain cross sectional dan analisa data bivariat dengan menggunakan uji chi-square. Penelitian ini dilaksanakan di Wilayah Kerja Puskesmas Siulak Mukai pada Mei Juli 2019. Jumlah populasi dalam penelitian ini adalah balita berusia 24-59 bulan yang ada di Wilayah Kerja Puskesmas Siulak Mukai yang berjumlah 311 dan tehnik penggambilan sampel menggunakan tehnik proporsional random sampling yang berjumlah 74 sampel. Data penelitian dikumpulkan dengan cara pengisian kuesioner, dan pengukuran tinggi badan. Analisis data status gizi $(\mathrm{TB} / \mathrm{U})$ menggunakan aplikasi WHO Anthro, selanjutnya data dianalasis secara univariat dan bivariat (chi-square test) menggunakan aplikasi SPSS.

\section{HASIL DAN PEMBAHASAN}

Hasil penelitian ini menunjukkan bahwa dari 74 responden dapat diketahui bahwa sebagian besar balita tidak stunting yaitu sebanyak $47 \quad(63,5 \%)$. Meskipun hasil penelitian menunjukkan status gizi balita tergolong normal, namun penelitian masih ini menemukan kejadian stunting sebesar 36,5\%. Hasil ini lebih tinggi dibandingkan dengan data Dinas Kesehatan Kabupaten Kerinci yaitu 35,0\%. Oleh karena itu, kejadian stunting di wilayah Puskesmas Siulak Mukai masih menjadi permasalahan gizi yang berat.

Stunting merupakan hal yang dianggap orang tua sebagai sesuatu yang biasa, dan banyak orang tua yang tidak mengetahui tentang 
stunting dan dampaknya bagi anak. Orang tua menganggap bahwa anak mereka masih bisa mengalami pertumbuhan sebab usianya masih balita padahal bila stunting tidak terdeteksi secara dini, minimal sebelum berusia 2 tahun maka perbaikan untuk gizinya akan mengalami keterlambatan untuk tahun berikutnya (Bayhakki, 2018). Sebanyak 50 responden $(67,6 \%)$ dengan lama pemberian ASI lebih atau sama dengan 2 tahun. Berdasarkan penelitian yang dilakukan oleh Djais dkk (2018) didapatkan hasil dari 65 responden sebanyak 10 responden $(15,4 \%)$ dengan lama waktu pemberian ASI 0-6 bulan, sebanyak 2 responden $(3,1 \%)$ dengan lama waktu pemberian ASI 7-9 bulan, sebanyak
5 responden $(7,7 \%)$ dengan lama pemberian ASI 0-12 bulan, sebanyak 32 responden $(49,2 \%)$ lama waktu pemberian ASI 13-24 bulan dan sebanyak 16 responden $(24,6 \%)$ dengan lama waktu pemberian ASI $>2$ tahun.

Status gizi normal merupakan suatu ukuran status gizi dimana terdapat keseimbangan antara jumlah energi yang masuk ke dalam tubuh dan energi yang dikeluarkan dari luar tubuh sesuai dengan kebutuhan individu. Energi yang masuk ke dalam tubuh dapat berasal dari karbohidrat, protein, lemak dan zat gizi lainnya (Nix, 2005). MP-ASI merupakan makanan tambahan bagi bayi. Makanan ini harus menjadi pelengkap dan dapat memenuhi kebutuhan bayi.

Tabel 2. Distribusi Frekuensi Kejadian Stunting, Lama Pemberian ASI, dan Berat Lahir Balita

\begin{tabular}{|c|c|c|c|}
\hline No & Variabel & $\mathbf{n}$ & $\%$ \\
\hline \multicolumn{4}{|c|}{ Kejadian Stunting } \\
\hline 1 & Normal & 47 & 63,5 \\
\hline 2 & Pendek & 27 & 36,5 \\
\hline & Jumlah & 74 & 100 \\
\hline \multicolumn{4}{|c|}{ Lama Pemberian ASI } \\
\hline 1 & $\geq 2$ tahun & 50 & 67,6 \\
\hline 2 & $<2$ taun & 24 & 32,4 \\
\hline & Jumlah & 74 & 100 \\
\hline \multicolumn{4}{|c|}{ Berat Lahir } \\
\hline 1 & Tidak BBLR & 49 & 66,2 \\
\hline 2 & BBLR & 25 & 33,8 \\
\hline & Jumlah & 74 & 100 \\
\hline
\end{tabular}

Hal ini menunjukkan bahwa MP-ASI berguna untuk menutupi kekurangan zat gizi yang terkandung dalam ASI. Dengan demikian, cukup jelas bahwa peranan makanan tambahan bukan sebagai pendamping ASI tetapi untuk melengkapi atau mendampingi ASI. Pada usia 6 bulan atau lebih ASI saja sudah tidak lagi dapat mencukupi kebutuhan nutrisi bayi, usia pasti pemberian MP-ASI yang tepat bisa bervariasi antar bayi dan bergantung pada perkembangan individual sistem metabolic dan neuromotorik anak tapi lebih disarankan sesudah berumur 6 bulan atau lebih (Eva Molika S, 2014).

Penelitian ini juga menemukan bahwa dari 74 responden sebanyak 
$49(66,2 \%)$ dengan kategori tidak BBLR. Hal ini sejalan dengan penelitian yang dilakukan oleh Nuryanto, dkk, (2016) yang menunjukkan bahwa riwayat berat badan lahir rendah bukan merupakan faktor risiko kejadian stunting dikarenakan sebagian besar anak tidak memiliki riwayat BBLR. Terdapat $94,4 \%$ anak pada kelompok kasus dan $97,2 \%$ anak pada kelompok kontrol yang tidak memiliki riwayat BBLR. Penelitian sebelumnya yang dilakukan di kabupaten Kendal pada balita menunjukkan hasil yang sama bahwa tidak ada hubungan berat badan lahir dengan kejadian stunting.

Anak dengan BBLR lebih beresiko untuk terjadi pertumbuhan stunting dibandingkan dengan anak dengan berat badan lahir normal, namun bukan berarti anak dengan BBLR tidak dapat mengejar pertumbuhan. Pengaruh berat badan lahir terhadap kejadian stunting paling tinggi pengaruhnya pada saat 6 bulan pertama. Pengaruh tersebut akan menurun hingga usia 24 bulan. Anak memiliki kemungkinan untuk dapat tumbuh normal apabila dalam 6 bulan pertama anak mengejar pertumbuhannya. Selain itu, terdapatnya riwayat BBLR tidak akan mempengaruhi pertumbuhan anak apabila anak mendapatkan asupan yang cukup dan kondisi lingkungan yang mendukung pertumbuhan dan perkembangan anak (Nuryanto dkk, 2016).

\section{Hubungan Lama Pemberian ASI dengan Kejadian Stunting}

Analisis hubungan lama pemberian ASI dengan kejadian stunting dapat dilihat pada Tabel 3 . Hasil menunjukkan bahwa dari 50 balita yang lama pemberian $\mathrm{ASI} \geq 2$ tahun sebagian besar status gizi (TB/U) normal $(92,0 \%)$. Sementara itu, dari 24 balita yang lama pemberian ASI <2 tahun sebagian besar status gizi (TB/U) stunting (93,8\%). Analisis chi-square diketahui bahwa ada hubungan signifikan antara lama pemberian ASI dengan kejadian stunting balita di Wilayah Kerja Puskesmas Siulak Mukai ( $p$-value $=0,000$ ). Hasil ini sejalan dengan penelitian yang dilakukan oleh Najah (2018) yang menyatakan bahwa ada hubungan yang bermakna antara lama pemberian ASI dengan kejadian stunting $(p=0,012)$. MP-ASI adalah makanan atau minuman yang mengandung gizi diberikan kepada bayi atau anak untuk memenuhi kebutuhan gizinya. MP-ASI diberikan mulai usia 6 bulan sampai 24 bulan. Semakin meningkat usia bayi atau anak, kebutuhan akan zat gizi semakin bertambah karena tumbuh kembang, sedangkan ASI yang dihasilkan kurang memenuhi kebutuhan gizi. MP-ASI merupakan makanan peralihan dari ASI ke makanan keluarga (Molika E, 2014). Oleh karena itu, diharapkan kepada pihak Puskesmas untuk memberikan edukasi terkait dengan pemberian ASI dan MP-ASI kepada ibu balita, sehingga diharapkan ibu mempertahankan pemberian ASI eksklusif selama 6 bulan yang dilanjutkan sampai anak berusia 2 tahun dan MP-ASI untuk balita agar dapat terhindar dari stunting. 
Tabel 3. Hubungan Lama Pemberian ASI dengan Kejadian Stunting di Wilayah Kerja Puskesmas Siulak Mukai Tahun 2019

\begin{tabular}{ccccccccc}
\hline No & Lama Pemberian & \multicolumn{4}{c}{ Kejadian Stunting } & \multirow{2}{*}{ Jumlah } & \multirow{2}{*}{$\boldsymbol{p}$-value } \\
\cline { 3 - 7 } & ASI & \multicolumn{2}{c}{ Normal } & \multicolumn{2}{c}{ Stunting } & & \\
\cline { 3 - 8 } & & $\mathbf{n}$ & $\mathbf{\%}$ & $\mathbf{n}$ & $\mathbf{\%}$ & $\mathbf{n}$ & $\mathbf{\%}$ & \\
\hline 1 & $\geq 2$ tahun & 46 & 92,0 & 4 & 8,0 & 50 & 100 & 0,000 \\
2 & $<2$ tahun & 1 & 4,2 & 23 & 93,8 & 24 & 100 & \\
& Jumlah & $\mathbf{4 7}$ & $\mathbf{6 3 , 5}$ & $\mathbf{2 7}$ & $\mathbf{3 6 , 5}$ & $\mathbf{7 4}$ & $\mathbf{1 0 0}$ & \\
\hline
\end{tabular}

Hubungan Berat Lahir dengan Kejadian Stunting

Analisis hubungan berat lahir dengan kejadian stunting dapat dilihat pada Tabel 4 di bawah ini.

Tabel 4. Hubungan Berat Lahir dengan Kejadian Stunting di Wilayah Kerja Puskesmas Siulak Mukai Tahun 2019

\begin{tabular}{|c|c|c|c|c|c|c|c|c|}
\hline \multirow[t]{3}{*}{ No } & \multirow[t]{3}{*}{ Berat Lahir } & \multicolumn{4}{|c|}{ Kejadian Stunting } & \multicolumn{2}{|c|}{ Jumlah } & \multirow[t]{3}{*}{ p-value } \\
\hline & & \multicolumn{2}{|c|}{ Normal } & \multicolumn{2}{|c|}{ Stunting } & & & \\
\hline & & $\mathbf{n}$ & $\%$ & $\mathbf{n}$ & $\%$ & $\mathbf{n}$ & $\%$ & \\
\hline 1 & Tidak BBLR & 41 & 83,7 & 8 & 16,3 & 49 & 100 & \\
\hline 2 & BBLR & 6 & 24,0 & 19 & 76,0 & 25 & 100 & 0,000 \\
\hline & Jumlah & 47 & 63,5 & 27 & 36,5 & 74 & 100 & \\
\hline
\end{tabular}

Berdasarkan Tabel 4 di atas diketahui bahwa dari 49 balita yang tidak BBLR (berat lahir $\geq 2500$ gram) sebagian besar status gizi (TB/U) normal $(83,7 \%)$. Sementara itu, dari 25 balita yang BBLR (berat lahir $<2500$ gram) sebagian besar status gizi (TB/U) stunting $(76,0 \%)$. Analisis chi-square diketahui bahwa ada hubungan signifikan berat lahir dengan kejadian stunting balita di Wilayah Kerja Puskesmas Siulak Mukai $\quad(p$-value $=0,000)$. Hasil penelitian ini sejalan dengan penelitian Aryastami et al., yang menyatakan bahwa berat badan lahir rendah merupakan faktor utama dari kejadian stunting pada anak umur 12-23 bulan di seluruh wilayah indonesia $(p=0,001)$.

Demikian pula studi Hal yang sama juga diperoleh Nasution (2014) berat badan lahir rendah mempunyai hubungan dengan kejadian stunting pada anak usia 6-24 bulan dengan risiko 5,6 kali lebih besar untuk menjadi stunting dibanding dengan riwayat kelahiran normal. Hal ini dikarenakan pada umumnya bayi dengan berat lahir rendah sulit untuk mengejar pertumbuhan secara optimal selama dua tahun pertama kehidupan. Kegagalan pertumbuhan yang mengakibatkan terjadinya stunting pada umumnya terjadi dalam periode yang singkat (sebelum lahir hingga kurang lebih umur 2 tahun), namun mempunyai konsekuensi yang serius di kemudian hari.

Menurut Winowatan et al. (2019), berat lahir pada umumnya sangat terkait dengan pertumbuhan dan perkembangan jangka panjang. Sehingga, dampak lanjutan dari BBLR dapat berupa gagal tumbuh (growth faltering). Seseorang bayi yang lahir dengan BBLR akan sulit dalam mengejar ketertinggalan 
pertumbuhan awal. Pertumbuhan yang tertinggal dari yang normal akan menyebabkan anak tersebut menjadi stunting. Berat badan lahir rendah adalah gambaran banyak masalah kesehatan masyarakat mencakup ibu yang kekurangan gizi jangka panjang, kesehatan yang buruk, kerja keras dan perawatan kesehatan dan kehamilan yang buruk. Secara individual, BBLR merupakan predictor penting dalam kesehatan dan kelangsungan hidup bayi yang baru lahir dan berhubungan dengan risiko tinggi pada anak. Oleh karena itu, bagi calon ibu dan ibu hamil perlu memperhatikan kualitas asupan ketika hamil agar tidak terjadi BBLR pada bayi yang dilahirkan.

\section{SIMPULAN}

Berdasarkan hasil penelitian maka dapat disimpulkan bahwa responden dengan kategori stunting sebanyak $27(36,5 \%)$ dan sebanyak $47(63,5 \%)$ dengan kategori normal. Sebagian besar lama pemberian ASI $\geq 2$ tahun $(67,6 \%)$, dan berat lahir $\geq 2500$ gram $(66,2 \%)$. Hasil analisis chi-square menunjukkan ada signifikan antara lama pemberian ASI dengan kejadian stunting $(p=0,000)$, berat lahir dengan kejadian stunting $(p=0,000)$.

\section{SARAN}

Berdasarkan hasil penelitian, diharapkan kepada ibu-ibu balita untuk menerapkan ASI Ekslusif dan melanjutkan pemberian ASI hingga usia balita 2 tahun. Selain itu, diharapkan pula kepada calon ibu dan ibu hamil untuk menerapkan gizi seimbang dan kualitas konsumsi selama kehamilan agar mencegah terjadinya Berat Bayir Lahir Rendah (BBLR) dan kejadian stunting.

\section{DAFTAR PUSTAKA}

1. Aruben., Rahfiludin., Astutik., 2018. Faktor Risiko Kejadian Stunting Pada Anak Balita Usia 24-59 Bulan (Studi Kasus Di Wilayah Kerja Puskesmas Gabus II Kabupaten Pati Tahun 2017). Jurnal Kesehatan Masyarakat, 6(1):2356-3346.

2. Aryastami NK, Shankar A, Kusumawardani N, Besral B, Jahari AB, 2017. Low birth weight was the most dominant predictor associated with stunting among children aged 12 - 23 months in Indonesia:1-6. doi:10.1186/s40795-017- 0130$\mathrm{x}$.

3. Bayhakki dkk, 2018. Hubungan Durasi Pemberian ASI Ekslusif Dengan Kejadian Stunting. JOM FKp, 5(2):184-192.

4. Dinas Kesehatan Provinsi Jambi, 2017. Jumlah Kejadian Stunting Di Provinsi Jambi Berdasarkan Kabupaten.

5. Djais dkk, 2018. Hubungan Pemberian ASI Ekslusif Dan Makanan Pendamping ASI Terhadap Balita Pendek Usia 2-5 Tahun Dikecamatan Jatinanggor. JSK, 3(3)

6. Fikawati, dkk. 2017. Gizi Anak Dan Remaja. Depok : Rajawali Pres

7. Kemenkes RI. 2018. Profil Kesehatan Indonesia tahun 2010. Jakarta : Kemenkes RI

8. Molika E. Buku Pintar MP ASI : Bayi 6 Bulan sampai dengan 1 Tahun. Jakarta: Lembar Langit Indonesia; 2014.

9. Nix S. W. 2005. Basic Nutrition \& Diet Therapy, 12th ed. Mosby-Year Book. St. Louis. 
10. Nasution D. 2014. Hubungan Berat Badan Lahir Rendah dengan Kejadian Stunting Pada Anak Usia 6-24 Bulan di Kota Yogyakarta. Tesis. Ilmu Kesehatan Masyarakat Universitas Gadjah Mada

11. Nuryanto \& Fauziah, 2016. Faktor Risiko Kejaidan Stunting Pada Anak Usia 1-3 Tahun (Studi Di Desa Menduran Kecamatan Brati Kabupaten Grobogan). Journal of Nutrition Collage , 5(4):314-320

12. Unicef, 1990 dalam Laporan Tahunan 2012. Penanggulangan Masalah Gizi. Unicef

13. Winowatan, G., Malonda, N. S., \& Punuh, M. I. (2019). Hubungan Antara Berat Badan Lahir Anak Dengan Kejadian Stunting Pada Anak Batita Di Wilayah Kerja Puskesmas Sonder Kabupaten Minahasa. KESMAS, 6(3). 